\title{
Familial chilblain lupus caused by an activating mutation in STING
}

\author{
N König ${ }^{1}$, C Fiehn², H-M Lorenz ${ }^{2,3}$, MA Lee-Kirsch ${ }^{1 *}$ \\ From 8th International Congress of Familial Mediterranean Fever and Systemic Autoinflammatory Diseases \\ Dresden, Germany. 30 September - 3 October 2015
}

Familial chilblain lupus is a monogenic form of cutaneous lupus erythematosus characterized by coldinduced cutaneous lesions at acral location. It is caused by loss-of-function mutations in the nucleic acid metabolizing enzymes TREX1 or SAMHD1. Gain-of-function mutations in STING (stimulator of Interferon genes) have been described in an infancy-onset autoinflammatory syndrome with fever, inflammatory cutaneous lesions and interstitial lung disease.

Here we report on a family with dominant chilblain lupus over 4 generations. Affected family members presented with acral inflammatory and partially necrotizing lesions beginning in early childhood. In some cases, low-titered ANAs and immune complexes were detectable. The family tested negative for TREX1 or SAMHD1 mutations. Exome sequencing revealed a heterozygous STING mutation segregating with chilblain lupus in the family. The mutation affects a highly conserved residue within the STING dimer interface and is predicted to be pathogenic. Quantitative RT-PCR analysis showed an increased expression of IFN-stimulated genes in blood cells of affected family members suggesting that the identified mutation has an activating effect on type I IFN signaling. Taken together, our findings demonstrate that gain-of-function mutations in STING can cause familial chilblain lupus and expand the spectrum of type I interferonopathies.

\section{Authors' details}

${ }^{1}$ Technische Universität Dresden, Molekulare Pädiatrie, Klinik für Kinder- und Jugendmedizin, Dresden, Germany. ${ }^{2}$ ACURA-Rheumazentrum, Baden-Baden, Germany. ${ }^{3}$ Universität Heidelberg, Sektion Rheumatologie, Medizinische Klinik $\checkmark$, Heidelberg, Germany.

Published: 28 September 2015

'Technische Universität Dresden, Molekulare Pädiatrie, Klinik für Kinder- und Jugendmedizin, Dresden, Germany

Full list of author information is available at the end of the article
doi:10.1186/1546-0096-13-S1-062

Cite this article as: König et al:: Familial chilblain lupus caused by an activating mutation in STING. Pediatric Rheumatology 2015 13(Suppl 1): O62.
Submit your next manuscript to BioMed Central and take full advantage of:

- Convenient online submission

- Thorough peer review

- No space constraints or color figure charges

- Immediate publication on acceptance

- Inclusion in PubMed, CAS, Scopus and Google Scholar

- Research which is freely available for redistribution

Submit your manuscript at www.biomedcentral.com/submit
() Biomed Central
C Biomed Central

C 2015 König et al. This is an Open Access article distributed under the terms of the Creative Commons Attribution License (http:// creativecommons.org/licenses/by/4.0), which permits unrestricted use, distribution, and reproduction in any medium, provided the original work is properly cited. The Creative Commons Public Domain Dedication waiver (http://creativecommons.org/publicdomain/ zero/1.0/) applies to the data made available in this article, unless otherwise stated. 